\title{
MAI E ACESTA OARE UN MEMORIAL?/
}

\section{IF THIS IS A MEMORIAL?}

Astrid ROTTMAN, drd. arh./ PhD.c. arch.

astridrottman@yahoo.com

Universitatea de Arhitectură şi Urbanism „Ion Mincu”, Bucureşti, RO/ „Ion Mincu” University of Architecture and Urbanism, Bucharest, RO

\begin{abstract}
Rezumat
Monumentele și memorialele amintesc trecutul, sunt destinate viitorului, dar sunt concepute astfel încât să slujească prezentului. Ca forme construite, sunt ridicate pentru a conferi semnificații dominante spațiului. Vizibile sau invizibile (aparent), ele sunt expresia unui text memorialistic vizual scris în spațiul public, iar împreună alcătuiesc un discurs cultural asociat memoriei colective a unei societăți. Structuri narative spațiale, memorialele ne conduc către experiențe senzoriale și fizice ce ascund simboluri. În funcție de educația, cultura și sensibilitatea celui ce privește, mesajul este descifrat și interpretat în diferite moduri. Orice interpretare este de fapt o recreare a spațiului gazdă, în cazul de față a memoriei, o reinterpretare și o rescriere a ei.
\end{abstract}

\begin{abstract}
Monuments and memorials are reminders of the past, designed for the future, but conceived in order to serve the present. As built structures, they are erected for conferring dominant significations to space. Apparent or (seemingly) unseen, they are the expression of a visual memorial text, written in the public space, creating together a cultural utterance associated to one society's collective memory. As spatial narrative structures, memorials lead us to sensorial and physical experiences containing hidden symbols. According to educational, cultural and sensitivity levels of the onlooker, the message is decoded and interpreted in different ways. Every interpretation is, in fact, a recreation of the host space, of the memory, in this case, a reinterpretation and a rewriting of it.
\end{abstract}


Într-un interviu recent (ianuarie 2020), Peter Eisenman ne reamintește de universul său conceptual legat de momentul în care a proiectat Memorialului Holocaustului din Berlin: "lipsa de sens a Shoah". Acest spațiu extrem de controversat, mai întâi prin reprezentare, iar mai apoi prin tipul de utilizare urbană, mi-a condus analiza către o altă narațiune de data aceasta literară: cartea lui Primo Levi, Mai e acesta oare un om?. Articolul de față propune o suprapunere vizuală a celor două reprezentări narative.

\section{Cuvinte cheie/ Keywords}

Holocaust, arhitectura memorială, memorie, Peter Eisenman, Primo Levi/

Holocaust, memorial architecture, memory, Peter Eisenman, Primo Levi
Recently (January 2020), in an interview, Peter Eisenman reminds us his conceptual universe connected to the moment when he designed the Holocaust Memorial from Berlin: „the meaningless of Shoah". This extremely controversial space, in the first place, by means of representation, and then by the way of urban utility, led my analysis to another narrative, a literal one this time, namely If This is a Man, the book of Primo Levi. This paper suggests a visual overlapping of the two narrative representations.

\section{Introducere}

Într-un interviu recent (Eisenman, 2020) în cadrul studioul său din New York, Peter Eisenman ne împărtășește la 15 ani de la inaugurare, gândurile și universul său conceptual din perioada în care a creat Memorialul Holocaustului din Berlin. Memorial to the Murdered Jews of Europe (în germană: Holocaust Mahnmal) este dedicat întregii evreimi europene care a pierit în cel de-al Doilea Război Mondial. Revenind asupra dorinței sale inițiale de a se îndepărta de orice simbol evreiesc, Eisenman descrie spațiul memorialului ca un "câmp al alterității", un spațiu în care te simți pierdut, un loc care sugerează prin experiența parcurgerii "lipsa de sens a Shoah".

Acest spațiu extrem de controversat, mai întâi prin reprezentare, iar mai apoi prin tipul de utilizare

\section{Introduction}

In a recent interview (Eisenman, 2020) taken in his New York studio, Peter Eisenman shares with us, after 15 years since the inauguration, his thoughts and his conceptual universe connected to the moment of designing the Berlin Holocaust Memorial. Memorial to the Murdered Jews of Europe (German: Holocaust Mahnmal) is dedicated to the entire European Jewry that perished in World War II. Back to his initial desire to move away from any Jewish symbol, Eisenman describes the memorial space as a "field of otherness", a space which make you feel lost, a place that suggests the "meaninglessness of the Holocaust."

The Holocaust Memorial from Berlin, this extremely controversial space, first because of its 
urbană, mi-a condus analiza către către o altă narațiune de data aceasta literară: cartea lui Primo Levi publicată în 1947 Mai e acesta oare un om?. Propun în rândurile care urmează o suprapunere vizuală a celor două reprezentări narative.

\section{Pe scurt despre arhitectura memorială}

\author{
“Putem trăi fără ea, \\ putem să o venerăm, \\ dar nu putem să ne amintim nimic fără ea."
}

(Ruskin, 2015, p.184)

De ce avem nevoie de arhitectură memorială? În primul rând pentru că prin existența ei, o societate recunoaște și își asumă public evenimentele importante din istoria sa. Trebuie să ne amintim și trebuie să comemorăm. Arhitectura memorială este expresia unei narațiuni ce pledează pentru valorile publice ale unei societăți.

Monumentele și memorialele ne amintesc trecutul, sunt destinate viitorului, dar sunt concepute astfel încât să slujească prezentului. Putem spune că ele reprezintă un text memorialistic vizual scris în spațiul public, iar împreună alcătuiesc un discurs cultural asociat memoriei unei societăți. Dar nu tot ceea ce s-a întâmplat în trecut este memorat sau comemorat în spațiul public. Asemeni unei persoane, o societate alege ce este semnificativ pentru ea și hotărăște ce trebuie sa devină memorabil pentru viitor. Gesturile memorialistice la nivelul unei comunități reflectă adesea valorile clasei sociale dominante și tind să excludă istoriile grupurilor minoritare. Dictatul ideologic al elitelor politice evaluează semnificația evenimentelor istorice și decide de cele mai multe ori asupra representation, and then by the type of urban utilization, led my analysis to another narrative, a literary one this time: Primo Levi's book If This Is a Man? published in 1947. I suggest in the following lines a visual overlapping of the two narrative representations.

\section{Briefly, about memorial architecture}

\author{
"We may live without her, \\ and worship without her, \\ but we cannot remember without her."
}

(Ruskin, 2015, p.184)

Why do we need memorial architecture? First of all, because, by means of its existence, a society publicly acknowledges and assumes the main events of its history. We must remember and we must commemorate. Memorial architecture is the expression of a narrative which pleads for the public values of a society.

Monuments and memorials are reminders of the past, designed for the future, but conceived in order to serve the present. We may say that they represent a memorial text written in the public space and create together a cultural utterance associated to one society's collective memory. But not all that happened in the past is memorized or commemorated in the public space. Like a person, a society selects what it believes that it's significant and decides what must become memorable for the future. Memorial gestures, at a community's level, often reflect the significations of the historical events and decide, most of the times, about the symbolistic language we use. The way people remember and appraise the past is influenced by the way of materialization and representation. The 
limbajului simbolic folosit. Felul în care oamenii își amintesc și apreciază trecutul este influențat de modul de materializare și reprezentare. Dimensiunea, materialele, mesajul transmis, locația, vizibilitatea, simbolistica, etc, sunt factori care rescriu vizual narațiunea și pot schimba semnificația evenimentului. Toate acestea modelează și manipulează memoria colectivă a unei națiuni.

Folosim adesea cuvântul monument sau memorial ${ }^{1}$ fără a face diferența între cei doi termeni. Dar cele două reprezentări, fie că sunt arhitecturale sau sculpturale, au un mesaj semantic diferit. Dacă dorim să evocăm persoane sau evenimente importante ce privesc identitatea pozitivă a unei comunități, în acest caz vorbim despre monumente, dar dacă scopul amintirii se îndreaptă către situații negative trăite de comunitate, alături de un mesaj care trimite către reflecție și analiză, atunci vorbim despre memoriale. Convențional, monumentul marchează un eveniment caracterizat prin triumf în timp ce memorialul evocă un moment marcat de pierdere. Ambii termeni provin din latinul monumentum care la rândul său derivă din verbul moneō ce înseamnă - a atrage atenția, a aminti, a avertiza. (Guțu, 1983) în extensie, numim monument un loc sau construcție cu o valoare deosebită sau o creație culturală ce are însemnătate națională sau internațională.

La inaugurarea Memorialului Veteranilor din Vietnam, în 1985, criticul și filozoful Arthur Danto sublinia de asemenea diferența semantică a celor doi termeni. Într-un articol publicat în The Nation el scria: „Construim monumente pentru a ne aminti mereu și construim memoriale pentru a nu uita niciodată" (Danto, 1985). El continuă spunând că monumentele comemorează ceea ce este dimensions, materials, the message conveyed, the location, visibility, symbolism and so on, are factors that visually rewrite narratives and might change the significance of the event. All those things mold and manipulate the collective memory of a society.

We often use the word monument or memorial ${ }^{1}$ without discerning the differences between those two notions. But the two representations, whether architectural or sculptural, hold different semantic messages. If we wish to evoke important persons or events concerning the positive identity of a community, in this case we talk about monuments, but if the purpose of the remembrance aims towards negative situations experienced by the community, along with a message leading to reflection and analysis, then we talk about memorials. By means of convention, a monument marks an event characterized by triumph, while the memorial evokes a moment marked by loss. Both terms come from the Latin monumentum which, in turn, originate from the verb moneō, meaning to draw attention, to remember, to warn. (Guțu, 1983) By extension, we name monument a place or a structure with a special value or a cultural creation with national or international significance.

In 1985, at the inauguration of the Vietnam Veterans Memorial, the critic and philosopher Arthur Danto wrote in The Nation: "We erect monuments so that we shall always remember and build memorials so that we shall never forget "(Danto, 1985). Furthermore, he states that monuments commemorate what is memorable and embodies those myths about beginnings, while memorials are 
memorabil și întruchipează acele mituri legate de începuturi, în timp ce memorialele sunt destinate amintirilor și reprezintă realitatea sfârșiturilor.

\section{Nevoia de a ne aminti}

În societățile post-conflict, consolidarea păcii necesită practici de aducere aminte. Comemorarea evenimentelor traumatice prin acte de memorializare constituie un gest esențial în procesul de reconciliere socială, iar sprijinul internațional în crearea acestui tip de spații se dovedește adesea decisiv.

Un raport (The Urge to Remember: The Role of Memorials in Social Reconstruction and Transitional Justice. 2015) elaborat de "United States Institute of Peace" în scopul de a oferi la nivel internațional recomandări celor interesați în procesul de memorializare, face un studiu de impact legat de aceste acte și inițiative. Promovează ele oare reconcilierea socială sau dimpotrivă, măresc diferendele care au generat conflictele și violența? Grupul de lucru a abordat cinci teme principale:

1. Ce este memorializarea și de ce este ea importantă?

2. Care este relația între memorializare și momentul intervențiilor din justiție?

3. Care este rolul "celor din afară" (organizațiile internaționale, ONG-urile, trupelor de menținere a păcii, etc) în acest proces?

4. Cum pot determina "cei din afară" comunitățile ce s-au aflat inițial în conflict să colaboreze ulterior în cadrul proiectelor memoriale? meant for memories and represents the reality of the ends.

\section{The Urge to Remember}

In post-conflict societies, peacebuilding requires remembrance practices. The essential gesture in the social reconciliation process is the commemoration of traumatic events through acts of memorialization, and this is where international support is often conclusive in creating these kinds of spaces.

The Urge to Remember: The Role of Memorials in Social Reconstruction and Transitional Justice (2015) was a report elaborated by the United States Institute of Peace, to provide at an international level, recommendations to those interested in the process of memorialization, and developed an impact study tied with these acts and initiatives. Does it promote social reconciliation or, on the contrary, does it increase the differences that have generated conflicts and violence? The working group addressed five main topics:

1. What is memorialization and why is it important?

2. What is the relationship between memorialization and the moment of judicial interventions?

3. What is the role of "outsiders" (international organizations, NGOs, peacekeeping troops, etc.) in this process?

4. Can "outsiders" determine how the communities that were initially in conflict, can now cooperate on these memorial projects? 
5. Ce impact are memorializarea în procesul de reconciliere și reconstrucție socială?

Comemorarea victimelor poate fi inițiată fie de supraviețuitori sau de comunitatea afectată, dar poate fi și o inițiativă politică, guvernamentală venită în sprijinul reconcilierii. Formele memorializării sunt multiple. Pot fi fizice, vorbim aici despre muzee, memoriale sau diverse intervenții private ce țin de locuri ce relaționează cu victimele (fotografii, inscripții, flori, note, etc), dar și virtuale. Mediul online a contribuit în ultimii ani cu o varietate surprinzătoare de gesturi comemorative.

A ne aminti, vorbi și a învăța despre Holocaust este important nu numai pentru că devenim capabili să înțelegem mai bine trecutul și istoria noastră, dar și pentru că, cu această ocazie, devenim conștienți și putem identifica mai clar formele contemporane de antisemitism, xenofobie sau ură. Toate acestea creează un context preliminar propice apariției unui genocid.

În cazul specific al Holocaustului, memorialele au două funcții esențiale. În primul rând oferă victimelor un loc și un nume spre comemorare. În tradiția iudaică locul de veci nu se transmite, el este individual. Ori modul în care au fost "tratate" victimele, lipsa cimitirelor și a pietrelor funerare, dorința de a șterge orice amintire din mentalul colectiv, reprezintă o cicatrice cumplit de adâncă în istoria poporului evreu. Numele memorialului din lerusalim - Yad vashem, în traducere un loc si un nume - încearcă să vindece această rană și să ofere victimelor un loc de comemorare și odihnă menit să fie transmis generațiilor viitoare.
5. What kind of impact does memorialization have in the process of reconciliation and social reconstruction?

The victims' commemoration can be initiated either by supervisors or by the affected community, but it can also be a political or a governmental initiative in support of reconciliation. There are multiple forms of memorization. They can be physical, like museums, memorials, or various private interventions that tie in places in relation with the victims (photographs, inscriptions, flowers, notes, etc.) but also virtual. The online environment has contributed in recent years with a surprising variety of commemorative gestures.

Remembering, discussing and learning about Holocaust is important not only because we are able to understand better our past and history, but also because, on this occasion, we become aware and we can identify more clearly the contemporary forms of antisemitism, xenophobia or hate. All those create a preliminary context auspicious for the emergence of a genocide.

In the specific case of Holocaust, memorials hold two essential functions. First of all, they provide for the victims a place and a name for commemoration. In the Jewish tradition, the burial site is not transmissible, it is unique for each person. Or, the way they "treated" the victims, the lack of cemeteries and tombstones, the desire to erase any memory from the collective mind, represents a terrible deep scar in the history of the Jewish people. The name of the Jerusalem memorial - Yad va shem, meaning a place and a name - tries to soothe that wound and to give the victims a place for commemoration and rest and a name meant to last for future generations. 
" Le voi da în Casa Mea și înăuntrul zidurilor Mele un loc și un nume (Yad Vashem) mai bune decât fii și fiice le voi da un nume veșnic, care nu se va stinge."

(Biblia, Isaia 56-5).

În Sala Numelor din incinta memorialului sunt expuse, până în prezent, bibliorafturi ce cuprind identitățile a aprox. 4,8 milioane de victime. Baza de date începută în 2004 se completează an de an prin paginile de mărturie trimise de către supraviețuitori sau urmașii acestora și reprezintă cea mai mare resursă folosită în căutarea celor ce se presupune că au pierit în timpul Holocaustului.

În al doilea rând memorialele au rolul de mărturie și reprezintă dovada ca Holocaustul a existat. Memorialul în cazul Holocaustului este un container al memoriei. Principalul său exponat este memoria, el expune prin excelență mărturia supraviețuitorilor, a martorilor și a urmașilor acestora. Arhitectura, așa cum spune Alberto Perez-Gomez, "așază în spațiu" (Perez-Gomez, 2018) acțiunile umane, așadar în cazul nostru arhitectura așază în spațiu acțiunea de a comemora și memora, a întipări, a recunoaște, a reproduce evenimente și sentimente. Memorialul este un loc de întâlnire. Pe de-o parte este amintirea, mărturia, memoria, iar pe de altă parte vizitatorul. Vizitatorul devine la rândul său martor. Rolul său de a transmite mai departe este esențial, mai ales în contextul actual în care memoria vie dispare. În cel mult 10-15 ani mărturia directă a supraviețuitorilor își va atinge limitele biologice.

A ne aminti, discuta și învăța despre Holocaust este important nu numai pentru că înțelegem mai bine trecutul și istoria noastră, ci și pentru că în acest fel conștientizăm și identificăm mai clar formele contemporane de antisemitism, xenofobie sau ură.
"To them I will give within my temple and its walls a memorial and a name (Yad vashem) better than sons and daughters; I will give them an everlasting name that will endure forever."

(Bible, Isaiah $56-5$ )

In the Hall of Names, inside the memorial, there have been exhibited, so far, bookshelves containing approx. 4.8 million victims' identities. The database was started in 2004 and it is completed yearly with testimony pages sent by the survivors or their descendants and it is the largest resource used in the search for those who are believed to have perished during the Holocaust.

Second, the memorials hold the role of a witness, represent the proof of Holocaust's existence. Memorials, in Holocaust's case, are containers of memory. Their main exhibit are the memories, they display par excellence the testimony of the survivors, the witnesses and their descendants. Architecture, as Alberto Perez-Gomez says „lays in space” (Perez-Gomez, 2018) human actions, so, in our case, architecture lays in space the action of memorizing: imprinting, recognizing, reproducing events and feelings. A memorial is actually a meeting place. On the one hand, remembrance, testimony therefore, memory - and on the other, the visitor. The visitor becomes, in turn, a witness. Its role in transmitting is essential, especially in the present context in which live memories vanish. No more than 10-15 years from now, the direct testimony of the survivors will reach its biological limits.

Remembering, discussing and learning about Holocaust is important not only because we are able to understand better our past and history, but also because, on this occasion, we become aware and we can identify more clearly the contemporary forms of 
Toate acestea creează un context propice pentru apariția unui viitor posibil genocid.

\section{Spațiul narativ}

Narațiunea este unul dintre cele mai importante instrumente cognitive care ne ajută să facem judecăți despre lucruri și evenimente, bazate pe emoțiile stârnite de o poveste.

Care sunt principalele ingrediente ale unei narațiuni? În primul rând putem observa că narațiunile spun o poveste, iar poveștile sunt populate de personaje. Poveștile pot fi relatate fie prin text vorbit sau scris, prin film sau imagine, sau printr-un act de interpretare. Prin urmare există o narațiune care spune o poveste, o poveste ce este o succesiune de evenimente în care există personaje și naratorul, persoana care articulează, cel ce vorbește textul respectiv (Jahn, 2020).

Memorialele expun fapte și spun povești trăite. Sunt spații conținătoare a unor narațiuni. Actul povestirii arhitecturale este esențial în construirea de spații menite să transmită mesaje semnificative. Arhitectul ca povestitor este cel ce face ca aceste clădiri și spații să vorbească.

În timp ce o narațiune este o cronologie a unor evenimente, arhitectura recurge la construcția unei narațiuni prin relaționarea spațiilor. Povestirile spuse de clădiri, conduc către experiențe și emoții nu prin compoziții formale oarecare, ci prin structurarea compozițională a spațiilor respective în jurul narațiunii. O clădire impune un anumit comportament uman sau anumite acțiuni umane în funcție de organizarea și relaționarea spațiilor componente.
anti-Semitism, xenophobia or hate. All those create a preliminary context auspicious for the emergence of a genocide.

\section{Narrative space}

Narration is one of the most important cognitive tools that helps us make judgments about things and events based on emotions triggered by a story.

What are the main ingredients of a narrative? First of all, we can observe that narratives tell a story and the stories are populated by characters. Stories can be told either through spoken or written text, by moving or still image, or by an act of interpretation. Therefore, there is a narrative that unfolds a story, a tale seen as a sequence of events where characters exist as well as the narrator, the one who articulates and vocalizes the story (Jahn, 2020).

Memorials exhibit facts and tell past living stories. They contain narratives. The act of architectural storytelling is essential for erecting spaces intended to convey significant messages. The architect perceived as a narrator is the one who gives a voice to buildings and spaces.

While a narrative is a timeline representation of events, architecture builds stories through establishing relations between spaces. Stories "told" by buildings lead towards experiences and feelings, not through formal random compositions, but by using compositional structures of spaces that surround narratives. A building requires a certain human behavior and certain human actions that depend on the organization and the relationships of the compound spaces. 
Dacă vorbim în sens literar, spațiul narativ este mediul în care personajele trăiesc și se mișcă. Este o descriere a unei lumi în care obiectele și personajele își găsesc locul. Spațiul narativ poate include peisaje, orașe, grădini sau încăperi. Include tot ceea ce poate fi conceput drept spațiu gazdă a unei povestiri.

\section{Revenind la Holocaust Mahnmal}

"În primul rând nu am avut nici o experiență personală legată de Holocaust și nu știam dacă îmi doresc cu adevărat să fac acest proiect" (Eisenman, 2020). Așa își începe interviul Peter Eisenman, iar sinceritatea mărturisirii este pe măsura controverselor care au marcat cei 15 ani scurși de la inaugurarea memorialului.

Etapa de proiectare și execuție a fost departe de a avea un traseu firesc și plăcut întinzându-se pe o perioadă de aproximativ 8 ani. Un amplasament situat în mijlocul Berlinului $\left(19,000 \mathrm{~m}^{2}\right)$, o presiune intruzivă imensă din partea politicului - cum comemorăm ceva ce noi am înfăptuit? - dar și din partea comunității evreiești care împingea, firește, spre o simbolistică comemorativă agreată: simboluri religioase specifice, cu referințe clare către numărul total de victime și nu numai.

Eisenman nu a vrut să folosească niciun element simbolic asociat iudaismului sau Shoah-ului. S-a inspirat însă din conversația pe care a avut-o cu o supraviețuitoare de la Auschwitz care, după ce a fost separată de mama ei, a avut o întâlnire terifiantă cu Josef Mengele ce a făcut-o să se simtă singură și pierdută în spațiu. Pentru Eisenman spațiul memorialului este „un câmp al alterității" în care oamenii să înțeleagă că a fi evreu în Germania însemna a fi un altul.
If we are talking in a literal sense, narrative space is the environment in which characters live and move. It is a description of a world where objects and characters find their place. Narrative space can include landscapes, cities, gardens or rooms. It includes everything that can be conceived as a host space for a story.

\section{Back to Holocaust Mahnmal}

"First of all, I had no experience of the Holocaust personally and I didn't know if I really wanted to do this project" (Eisenman, 2020). So begins the interview with Peter Eisenman, and the frankness of his confession suits the controversies that stamped the 15 years from the memorial's inauguration.

The designing and working stage were far from having a natural and pleasant route. it took about 8 years. A site in the middle of Berlin (19,000 sqm), a tremendous and intrusive pressure from the political class - how can we commemorate something we have done? - and, in the same time, from the Jewish community, who pushed, naturally, towards an agreed commemorative symbolistic, with specific religious symbols and mentions of the 6 million victims.

Eisenman didn't wish to use any symbolic item associated with Judaism or Shoah. He claims taking inspiration from the conversation with a survivor from Auschwitz. After being separated from her mother, she had a terrifying encounter with Josef Mengele, which made her feel alone and lost in space. For Eisenman, the memorial space is "a field of otherness" in which people would understand that being a Jew in Germany meant being the other. 
Grila formată din cele 2711 blocuri de beton este astăzi un spațiu public de referință al Berlinului. Este parcurs și frecventat zilnic de către oameni, adesea fără legătură cu semnificația în sine a locului. Memorialul a devenit un container al memoriei colective contemporane. Memoria Holocaustului a devenit parte din memoria personală a celor care îl "folosesc" în timp ce spațiul edificat de Eisenman "suspendă eforturile arhitectului de a vorbi, tăcând arhitectural, despre lipsa de sens a Holocaustului" (Ioan, 2013, p.14).

\section{Primo Levi și datoria de a fi martor}

Memorialul Holocaustului din Berlin, un spațiu extrem de controversat, in primul rând prin reprezentare si mai apoi prin tipul de utilizare urbană, mi-a condus analiza către o altă narațiune de data aceasta literară: cartea lui Primo Levi Mai e acesta oare un om?. O lectură parcursă încă din anii liceului a cărei atmosferă spaţială am regăsit-o ulterior în timpul parcurgerii memorialului creat de Eisenman 60 de ani mai târziu.

Primo Levi (1919-1987), un tânăr chimist născut la Torino, a fost deportat la Auschwitz când avea 24 de ani. A reușit surprinzător să supraviețuiască fiind eliberat la sosirea Armatei Roșii. Manuscrisul cărții a fost scris în primul an de libertate.

Ce înseamnă viața într-un lagăr de exterminare? Mai este posibil să-ți păstrezi umanitatea într-un loc special proiectat să dezumanizeze? Vorbim de cel mai diabolic experiment pentru a stabili "ce este esențial și ce este dobândit în comportamentul animalului-om în lupta pentru existență” (Levi, 1974, p. 123).
The 2711 concrete blocks grid is a reference of Berlin's today public spaces. It is frequented daily by people, often unrelated to the very meaning of the place. The memorial has become a container of contemporary collective memory. The memory of the Holocaust became a part of the personal memory of those who cross the space built by Eisenman while it "suspends the architect's efforts to speak, silently architecturally, about the meaninglessness of the Holocaust" (Ioan, A. 2013. p.14).

\section{Primo Levi and the duty to be a witness}

The Holocaust Memorial from Berlin, an extremely controversial space, first because of the representation, and then by the type of urban utilization, led my analysis to another narrative, a literary one this time: the book of Primo Levi If This Is a Man? A book I read in high school and whose spatial atmosphere I explored 60 years later when I first saw the space created by Eisenman.

Primo Levi (1919-1987), a young chemist born in Turin, Italy, was sent to Auschwitz at the age of 24. He surprisingly managed to survive being released by the arrival of Red Army. The manuscript of the book was written in the first year subsequent to his release.

What was the meaning of life in an extermination camp? Was it still possible to maintain one's human characteristics in a place specifically meant to dehumanize? Inside of the "most diabolical experiment to establish what is essential and what is adventitious to the conduct of the human animal in the struggle for life" (Levi, 1958, p. 99). 
Ce este de menționat în primul rând, este faptul că în lagăr, unul din motivele care i-au determinat pe cei deportați să reziste și să supraviețuiască a fost dorința lor de a deveni martori. Martorul depinde la rândul său de o a doua persoană care îi receptează relatarea. Aflat încă la Auschwitz, Primo Levi avea adeseori temerea că va reveni acasă și că nimeni nu va dori să-i asculte povestea. În lipsa receptării, supraviețirea sa - dacă acesta e motivul pentru care și-a dorit să rămână în viață - devine zadarnică. Și dacă reușești sa supravieţuiești, cum faci să rămâi om? Supraviețuitorul este depozitarul memoriei, el nu poate să uite si are datoria să-și amintească. "Amintirile din perioada detenției mele sunt mult mai vii și mai detaliate decât orice s-a petrecut înainte sau după. ........ mi s-a întâmplat ceva anormal, aș spune aproape o pregătire inconștientă pentru mărturie" (Levi, Belpoliti, \& Gordon, 2001, p.225).

Viața în lagăr este lipsită de perspectivă, obsedant conectată către preocupări de bază legate de supraviețuire. Nimic nu contează în afara scopului de a mai trăi o zi, de a mai face un pas în față. Vorbim despre ritm, repetiție, lipsa libertății de mișcare. Totul este controlat prin sarcini, totul este epuizant, totul este infernal.

Șirul deținuților, grila umană a careului, liniștea și absurdul sarcinilor, pașii sacadați, griul cerului, paloarea chipurilor, toate își regăsesc parcă locul în prezent printre blocurile din beton înșiruite ale memorialului. Vizitatorul de azi este introdus involuntar în același ritual scenic al mișcărilor controlate. Oamenii dispar într-o clipa coborând prin spaţiile înguste. Par captivi și sunt supuși unui regim de mișcare identic pentru toți.
What is to be mentioned, in the first place, is the fact that in the concentration camp, one of the reasons that determined the prisoners to resist and survive was their desire to become witnesses. The witness depends on a second person to receive his report. While still in Auschwitz, Primo Levi often feared that he would return home and no one will want to hear his story. In the absence of reception, his survival - if this is why he wanted to stay alive - becomes futile. And if you manage to survive, how do you manage to remain human?

The survivor is the repository of memory, he can't not remember and he has the vocation and the duty of remembering. "The memories from my detention period are much more vivid and detailed than anything happened before or after. ......... something abnormal happened to me, I would say almost an unconscious preparation for testimony" (Levi, Belpoliti, \& Gordon, 2001, p. 225).

Life, in a concentration camp, lacks of expectation, is obsessively connected to basic concerns about survival. Nothing matters beside one's aim to live another day, to make another step forward to a so less likely release. We talk about rhythm, recurrence, no freedom of movement. All is controlled by chores, all is exhausting, all is infernal.

The row of prisoners, the square human grid, the silence and absurdity of the daily tasks, the jerky steps, the gray sky, the pallor of the faces, all seem to find their place today among the lined concrete blocks of the memorial. Today the visitors are involuntarily introduced into the same scenic ritual of controlled movements. People disappear in an instant descending through the narrow spaces. They seem captive and are the subject of a controlled movement which is identical for all. 
Voi cita câteva fragmente din cartea lui Primo Levi și voi lăsa imaginația în timp ce le parcurgem să ne poarte pașii printre blocurile din beton ale memorialului.

„așa au dispărut într-o clipă .... femeile noastre, părinții noștri, copiii noștri. Aproape nici unul nu a avut cum să-și ia rămas bun." (Levi, 1974, p.22)

„Așa va decurge viața noastră. În fiecare zi în ritmul stabilit." (Levi, 1974, p.46)

„Amestecătura asta imensă de fier și ciment, de noroi și de fum e negarea frumuseții." (Levi, 1974, p.100)

"Să închizi între fire de sârmă ghimpată mii de indivizi de vârste, condiţii, origini, limbi, culturi şi obiceiuri diferite şi să-i supui unui regim de viaţă constant, controlabil, identic pentru toţi." (Levi, 1974, p.122)

„În viață de obicei individul nu e singur, ci, în urcuşul şi coborâşul său, este legat de destinul celor din jur." (Levi, 1974, p. 123)

„Dacă aș putea aș face 10 pași spre stânga” (Levi, 1974, p.185)

\section{Concluzii}

În luna mai 2005, imediat după inaugurare, Eisenman declara într-un interviu în publicația Spiegel: „Chiar ieri, am văzut cum oamenii îl parcurg pentru prima dată și este uimitor cum dispar aceste capete ... Primo Levi vorbește despre o idee similară în cartea sa despre Auschwitz" (Spiegel, 2005, May 09).

Eisenman mărturisește cu sinceritate cât de mult a învățat în timp ce a realizat proiectul. Spre surprinderea autorului, spațiul imaginat pe hârtie devine o data cu zămislirea lui fizică spațiul narativ
I'll insert, next, a few quotes from Primo Levi's book and let our imagination run as we walk through the stelae of the memorial.

„Thus, in an instant, our women, our parents, our children disappeared. We saw them for a short while as an obscure mass at the other end of the platform; then we saw nothing more." (Levi, P. 1958. p. 12)

"Such will be our life. Every day, according to the established rhythm." (Levi, P. 1958. p. 32)

„This huge entanglement of iron, concrete, mud and smoke is the negation of beauty." (Levi, P. 1958. p. 81)

"Thousands of individuals, differing in age, condition, origin, language, culture and customs are enclosed within barbed wire: there they live a regular, controlled life which is identical for all" (Levi, P. 1958. p. 99)

„A man is normally not alone, and in his rise or fail is tied to the destinies of his neighbors." (Levi, P. 1958. p. 100)

„If I could walk ten steps to the left” (Levi, P. 1958. p. 153)

\section{Conclusions}

In May 2005, after the inauguration, Eisenman stated in an interview in Spiegel: „Just yesterday, I watched people walk into it for the first time and it is amazing how these heads disappear ... Primo Levi talks about a similar idea in his book about Auschwitz" (Spiegel, 2005, May 09).

Eisenman sincerely confesses how much he learned while doing the project. By the author's surprise, the space imagined on paper becomes, with its physical birth, the narrative space where the Levi's book 
în care personajele cărții lui Levi își regăsesc parcă azi locul. Memorialul impune un anumit comportament uman. Povestea spusă de grila celor 2711 blocuri din beton transferă vizitatorii în spațiul coercitiv al lagărului de concentrare nazist.

Într-un articol scris cu ocazia inaugurării memorialului, Giorgio Agamben lega de asemeni printr-o subtilă paralelă cele două referințe narative prezentate mai sus. Trebuie menţionat că în cartea sa Ce rămâne din Auschwitz. Arhivă și martorul, el face o deconstrucție a mărturiei, a valorii ei etice și juridice, a responsabilităţii supraviețuitorului în calitatea lui de martor, bazată în principal pe cartea lui Primo Levi.

În articolul său, Agamben face referire la două tipuri de memorie: memoria scrisă, amintită, arhivată în documente, și memoria de neuitat cea care este nescrisă dar rămâne în subconștientul nostru printro experiență trăită la un moment dat.

În Evul Mediu, memoria a fost deseori comparată cu o carte. ... Nu este nimic de citit în cartea pietrificată a memoriei lui Peter Eisenman. Totuși, oricine se plimbă printre blocurile de înălțimi diferite ... simte că a intrat într-o altă dimensiune a memoriei, ... că răsfoiește paginile unei alte cărți. În timp ce ezită să pună piciorul pe paviment, iar privirea lui se pierde în zare, el lasă treptat în urmă memoria care poate fi inregistrată și arhivată. (Agamben G. 2005)

Ce nu uităm și ce ne amintim nu este același tip de memorie. Parcurgând monumentul edificat de Eisenman înțelegem că adevărul de neuitat nu poate fi arhivat în documente. El este sedimentat adânc în characters find their place today. The memorial imposes a certain human behavior. The story told by the grid of the 2711 concrete blocks transfers the visitors into the coercive space of the former Nazi concentration camp.

In an article written on the occasion of the memorial inauguration, Giorgio Agamben also connects through a subtle parallel the two narrative references featured in this paper. It must be mentioned that in his book, Remnants of Auschwitz: The Witness and the Archive, he performs a deconstruction of the testimonial, of the testimony's ethical and legal values, of the survivor's responsibility as a witness of those what happened before his eyes, based mainly on Primo Levi's book.

In his article, Agamben writes about two kinds of memory: the written memory, remembered, archived in documents, and the unforgettable memory, the one that was not written, but persists in our subconsciousness by something experienced at a certain time.

In the Middle Ages, memory was often compared to a book. ... There is nothing to read in the petrified memory book of Peter Eisenman's. However, anyone who walks among the different height stelae ... feels that he has entered in another dimension of memory, ... as he flips through the pages of another book. As he hesitates to put his foot on the floor and his gaze is lost in the flight of vertical stelae, he gradually leaves behind the memory that can be recorded and archived. (Agamben G. 2005)

The unforgettable and the remember-able are not the same type of memory. When we walk through the Eisenman monument we understand that the "unforgettable" cannot be archived in documents. It 
memoria individuală și colectivă fiind covârșitor ca proporție în raport cu amintirea conștientă. is deeply settled out in individual and collective memory and is overwhelming in proportion to conscious remembrance.

\section{Referinţe/ References}

Agamben, G. (2005). The two memories. ZEIT ONLINE. (n.d.). Retrieved September 12, 2020, from https://www.zeit.de/2005/19/Mahnmal_2f_Agamben

Danto, A. C. (1985, August 31). The Vietnam Veterans Memorial. The Nation, Retrieved September 12, 2020, from https://www.yumpu.com/en/document/view/45112605/arthur-danto-the-vietnam-veterans-memorial

Eisenman, P. (2020, April 28). Field of Otherness. Retrieved September 12, 2020, from https://channel.louisiana.dk/video/peter-eisenman-field-of-otherness

Ioan, A. (2013). Arhitectura memoriei: noua frontieră a spațiului sacru. Bucharest: Igloo

Jahn, M. (2020). Narratology 2.1: A Guide to the Theory of Narrative. English Department, University of Cologne, Retrieved September 12, 2020, from https://www.uni-koeln.de/ ame02/jahn_narratology2.1.pdf

Guțu, G. (1983). Dicționar latin-român, Bucharest: Editura științifică și enciclopedică

Levi, P. (1974). Mai e acesta oare un om?. (D. Condrea-Derer, Trans.). Bucharest: Editura Univers

Levi, P. (1959). If this is a man?. (S. Woolf, Trans.). New York: The Orion Press

Levi, P., Belpoliti, M., \& Gordon, R. S. (2001). The voice of memory: Interviews, 1961-1987: Primo Levi. New York: New Press.

Perez-Gomez, A. (2018) Consonanțe - Semnificația arhitecturală după crizele științei moderne. (A. Pandele, Trans.). Bucharest: Editura Fundației Arhitext design

Ruskin, J. (2015). Cele șapte lampi ale arhitecturii. (M. Teodorescu, Trans.). Bucharest: Editura Universitară „Ion Mincu”

Spiegel, D. (2005, May 09). SPIEGEL Interview with Holocaust Monument Architect Peter Eisenman: "How Long Does One Feel Guilty?" Retrieved September 12,2020 from https://www.spiegel.de/international/spiegel-interviewwith-holocaust-monument-architect-peter-eisenman-how-long-does-one-feel-guilty-a-355252.html

The Urge to Remember: The Role of Memorials in Social Reconstruction and Transitional Justice. (2015, February 03). Retrieved September 12,2020 from https://www.usip.org/publications/2007/01/urge-remember-role-memorialssocial-reconstruction-and-transitional-justice

1 Dex: MONUMÉNT, operă de sculptură sau de arhitectură destinată să perpetueze amintirea unui eveniment sau a unei personalități remarcabile; MEMORIAL, care servește pentru a aminti un eveniment însemnat, o persoană etc.; comemorativ./ Dex: MONUMÉNT, a sculpture or architecture work designed to perpetuate the memory of an event or a remarkable personality; MEMORIAL, which serves to commemorate a significant event, a person, etc.; commemorative. 